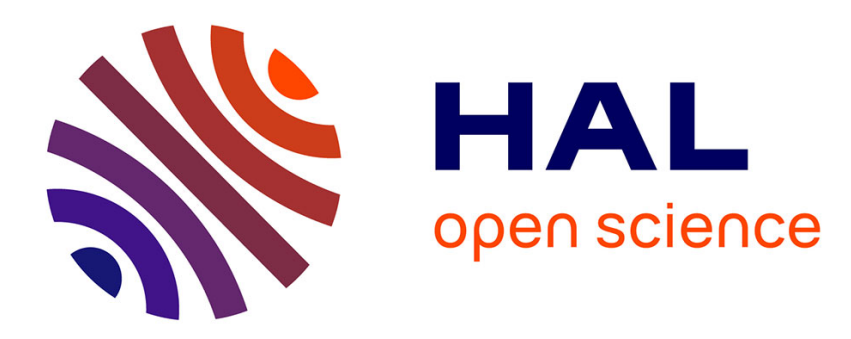

\title{
For an Age-Relevant Policy: Where to Live in Old Age? \\ Gérard-François Dumont
}

\section{To cite this version:}

Gérard-François Dumont. For an Age-Relevant Policy: Where to Live in Old Age?. Population et avenir, 2006, 680, pp.3. 10.3917/popav.680.0003 . hal-01316048

\section{HAL Id: hal-01316048 \\ https://hal.science/hal-01316048}

Submitted on 14 May 2016

HAL is a multi-disciplinary open access archive for the deposit and dissemination of scientific research documents, whether they are published or not. The documents may come from teaching and research institutions in France or abroad, or from public or private research centers.
L'archive ouverte pluridisciplinaire HAL, est destinée au dépôt et à la diffusion de documents scientifiques de niveau recherche, publiés ou non, émanant des établissements d'enseignement et de recherche français ou étrangers, des laboratoires publics ou privés. 


\section{For an Age-Relevant Policy: Where to Live in Old Age?}

Source: Population \& Avenir, No. 680, November-December 2006,

www.population-demographie.org/revue03.htm ; www.cairn.info/revue-population-et-avenir.htm

\section{This slightly provocative formulation was the title of the invitation to a conference organised by the association Population et Avenir ${ }^{1}$ in Nice in September 2006. It was an opportunity for the many partici- pants to discover the fifth special issue of the journal Population et Avenir ${ }^{2}$ and to hear twenty presentations.}

I

presented the conclusions to the conference in the shape of a magic square the first side of which was the rough answer to the questions:

- Where to live? where to spend one's old age? The answer is nearly a tautology. The choice is quite simply to live and become old ${ }^{3}$ at home, in a home sheltering one's geographic and symbolic identity, or sometimes a chosen home. But this simple answer has many implications. It means: having a dwelling that you quite like in an area which feels like home. This raises the issue of housing policies, and of dwellings adapted to the needs of people with disabilities (temporary or permanent) or with reduced mobility by reason of their age. It also raises the issue of urbanism, with a valued environment for these dwellings.

- A second side of the magic square concerns the ability to maintain family and social links. Human

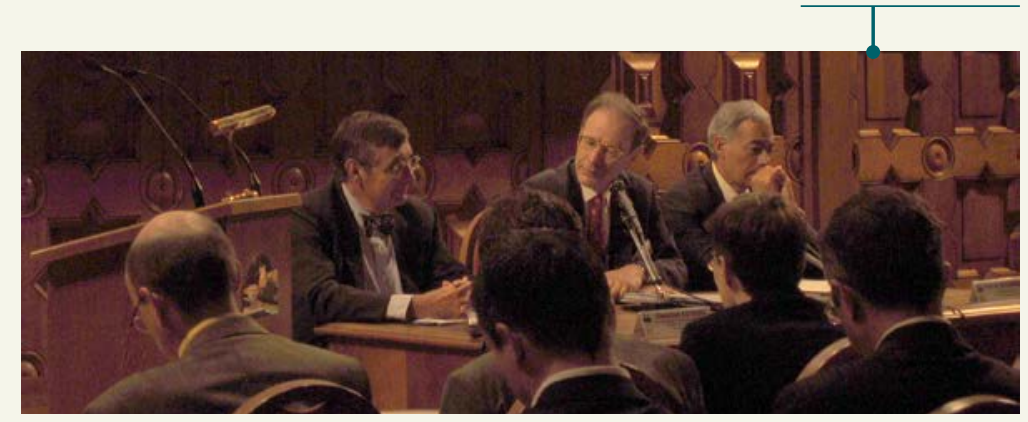

1. This conference, co-organised by the Caisses d'épargne pour la solidarité foundation, was held under the aegis of the minister in charge of land-use planning, Mr Christian Estrosi, and was sponsored by the following institutions: Conseil général des Alpes-Maritimes, Région Provence-Alpes-Côte d'Azur, Fondation de France, MAIF and MGEN.

2. Population et Avenir, "Territoire au banc d'essai : la France du Sud-Est», special issue, $n^{\circ} 679$ bis, September-0ctober 2006.

3. Cf. also Dumont, Gérard-François et alii, Les territoires face au vieillissement en France et en Europe, Paris, Ellipses, 2006. beings are not just individuals who live alone 4 , they evolve within families and society, and appreciate the possibility of integrating networks of relatives, friends, associations... A human being must therefore be free to found a household, a family - which requires a family-related housing policy - and to have exchanges with other people of their choice - which requires inter alia a well-adapted communication infrastructure. For these links to weave social fabric and contribute to social harmony requires not only social mingling, as is often suggested, but also a mix of generations, an aspect often omitted although it is an essential element to give life its variety.

- The availability of services to individuals and families, diversified and adapted, constitutes a third side of the magic square. For people to live in a district where they will bring up children and teenagers, work, become old, a range of domestic, commercial, health services is needed... While nannies or nurseries allow parents to reconcile work and family life in accordance with the wishes of each individual or couple, at the other end of the age range home assistance, often combining everyday domestic help and medical support, allows older people to continue living at home.

- The fourth side of the square is the exercise of citizenship. The lack of citizen actions entails two different risks: either the area is undermined by power struggles, even by violent acts many of which are covered by a code of silence, or the social link is lost in a system of simple handouts which dulls the sense of responsibility in individuals and leaves the field free for the unlimited development of selfish behaviour, to the detriment of humanistic values.

The analysis of this magic square leads to the formulation of political principles. Indeed it calls for an age-relevant policy which aims at establishing a good age equilibrium, welcoming to the young but also open to older people and, through a reasoned implementation of the principle of subsidiarity, helps build living areas conducive to more social cohesion, improving general wellbeing and fulfilment.

(Translation: Sylvie Vanston) 